\title{
PEMBERDAYAAN IBU-IBU PKK MELALUI PELATIHAN ENGLISH FOR BUSINESS DAN ENGLISH FOR TOURISM DI DESA SUKARESIK KECAMATAN SINDANGKASIH KABUPATEN CIAMIS
}

\author{
Andi Rustandi*, R. Bunga Febriani, Bambang Ruby Sugiarto \\ Universitas Galuh \\ *Email: andi27061980@gmail.com
}

\begin{abstract}
ABSTRAK
Pelatihan ini bertujuan untuk memberdayakan ibu-ibu PKK Desa Sukaresik melalui pelatihan English for Business dan English for Tourism untuk mengembangkan pemasaran produk kerajinan sebagai salah satu cara untuk meingkatkan kesejahteraan keluarga miskin di kabupaten Ciamis. Sasaran dari pelatihan ini adalah ibu-ibu PKK Desa Sukaresik, Kecamatan Sindangaksih, Kabupaten Ciamis. Dengan harapan, mereka mempunyai kemampuan dasar berkomunikasi bahasa Inggris yang baik dan benar untuk memasarkan kerajinannya. Metode yang digunakan tim pengabdian adalah mentransfer ilmu komunikasi English for Business dan English for Tourism pada ibu-ibu PKK melalui pelatihan. Pelatihan mencakup 1) memberikan materi dasar English for Business dan English for Tourism, dan 2) Melakukan praktek komunikasi bahasa Inggris untuk bisnis..
\end{abstract}

Kata kunci: English for Business, English for Tourism

\section{PENDAHULUAN}

Pelatihan English for Business dan English for Tourism untuk ibu-ibu PKK merupakan hal yang sangat penting dan merupakan salah satu skill komunikasi dalam bisnis. Hal ini sangat penting untuk di kuasai oleh siapapun yang ingin berjiwa wirausaha dan ingin sejahtera. Keuntungan menguasai bahasa inggris untuk bisnis dan EFT, ibu-ibu PKK akan menambah usaha lebih maju dan mempunyai brand bisnis yang dikenal bagus oleh orang banyak karena ada kolaborasi dengan organisasi dari luar negeri.

Kegiatan pengabdian pada masyarakat ini bertukuan untuk: (1) Memberikan pengetahuan dasar bagi Ibu-Ibu PKK tentang bahasa Inggris untuk bisnis, dan (2) Memberikan praktik komunikasi dengan bahasa Inggris untuk bisnis secara sederhana kepada ibu-ibu PKK.

\section{BAHAN DAN METODE}

Khalayak sasaran yang dipilih adalah para Ibu-Ibu PKK yang terdiri atas 30 orang dan beberapa anggota karang taruna yang dipilih dari 4 dusun yang ada di Desa Sukaresik. Sumber daya manusia merupakan fondasi yang kuat yang harus terlebih dahulu ditingkatkan. Dalam hubungan dengan dunia usaha, untuk meningkatkan kesejahteraan kemampuan berbahasa merupakan modal utama untuk berbisnis. Oleh karena itu, pelatihan bahasa Inggris untuk bisnis dituntut untuk bisa memotivasi ibu-ibu PKK agar mampu menciptakan situasi dan peluang usaha yang lebih luas untuk meningkatkan dan mengembangkan pemasaran yang lebih luas. 
Pemberdayaan Ibu-ibu PKK Melalui Pelatihan English For Business Dan English For Tourism di Desa Sukaresik Kecamatan Sindangkasih Kabupaten Ciamis

Andi Rustandi, R. Bunga Febriani, Bambang Ruby Sugiarto

Pelaksanaan kegiatan pengabdian berlangsung pada hari Jumat dan Sabtu, 1 dan 2 Maret 2019 dari jam 08.00 WIB s.d 11.00 WIB, dengan dihadiri 30 peserta Ibu-Ibu PKK. Kegiatan pengabdian berlangsung di ruang aula Desa Sukaresik. Kegiatan pengabdian diawali dengan penyampaian materi pokok kegiatan berhubungan dengan English for Business dan English for Tourism. Kemudian, pemateri menggunakan media film dalam mengajarkan percakapan bahsa Inggris sekaligus diterapkan dalam percakapan bahasa Inggris. Kegiatan percakapan bahasa Inggris langsung dipraktekkan oleh Ibu-Ibu PKK.

Sarana prasarana sangat menentukan dalam keberhasilan usaha. Kegiatan pelatihan ini akan sangat tergantung pada fasilitas. Pelaksanaan pengabdian ini menggunakan metode penyuluhan dan pelatihan yang diselenggarakan bersama dengan mahasiswa dan ibu-ibu PKK Desa Sukaresik, Kecamatan Sindangkasih. Palatihan dilaksanakan selama 2 hari pelaksanaan yakni tanggal 1 Maret dan 2 Maret 2019. Kegiatan ini dilakukan bersamaan dengan kegiatan KKN mahsiswa Universitas Galuh Periode I Tahun Akademik 2018/2019. Selain itu, kegiatan ini terdiri atas 2 sesi yakni seksi pemberian materi berupa workshop dan praktik menggunakan bahasa Inggris yang dilakukan oleh para mahasiswa KKN jurusan pendidikan bahasa Inggris.

\section{HASIL DAN PEMBAHASAN}

Konsep pemberdayaan masyarakat merupakan bentuk dari pembangunan yang berpusat pada manusia. Menurut Anshar (2017), pemberdayaan berasal dari kata "daya" yang berarti kekuatan, "berdaya" berarti mempunyai kekuatan. Pemberdayaan artinya membuat sesuatu menjadi berdaya atau berkekuatan. Menurut Carlzon dan Macauley dalam Anshar (2017), pemberdayaan adalah membebaskan seseorang dari kendali yang kaku; memberi kebebasan untuk bertanggung jawab terhadap ide-idenya.

Menurut sejarahnya, PKK semula merupakan akronim dari Pendidikan Kesejahteraan Keluarga yang bertujuan untuk melibatka partisipasi wanita melalui program pendidikan perempuan. Kemudian, pada tanggal 27 Desember 1972 organisasi tersebut berubah nama menjadi Pembinaan Kesejahteraan Keluarga yang bertujuan untuk membina dan membangun keluarga dibidang mental, spiritual dan fisik serta peningkatan mutu pangan, sandang, kesehatan, dan lingkungan hidup. Anggotanya adalah tokoh/pemuka masyarakat, para isteri Kepala dinas/jawatan dan isteri kepala daerah sampai dengan tingkat desa dan kelurahan yang kegiatannya didukung dengan anggaran pendapatan dan belanja daerah.

Kesejahteraan keluarga menjadi tujuan utama PKK. Hal ini dikarenakan keluarga merupakan unit terkecil masyarakat yang akan berpengaruh besar terhadap kinerja 
pembangunan dalam mendukung program-program pemerintah. Dari keluarga yang sejahtera ini, maka tata kehidupan berbangsa dan bernegara akan dapat melahirkan ketenteraman, keamanan, keharmonisan, dan kedamaian. Dengan demikian, kesejahteraan keluarga menjadi salah satu tolak ukur dan barometer dalam pembangunan dengan program-program pemerintah.

English for Bussiness sebagai penunjang jiwa wirausaha menurut Evan (2015), bahasa Inggris untuk bisnis sangat erat kaitanya dengan teknologi. Perkembangan teknologi yang begitu pesat memberikan sudut pandang baru dalam melihat bisnis. Kini, urusan bisnis sudah lintas luar negeri dan ini sangat mudah diterapkan. Jarak yang begitu jauh kerap menjadi jurang pemisah yang kini sudah terjembatani dengan adanya akses internet.

Pelaksanaan kegiatan pengabdian ini bertujuan untuk berbagi wawasan dalam komunikasi bahasa Inggris untuk bisnis. Selain itu, juga memberikan bekal teknik English for business dan English for Tourism untuk ibu-ibu PKK sebagai sarana komunikasi untuk pemasaran produk kerajinan tangan. Kegiatan ini diikuti oleh kurang lebih 30 Ibu-ibu PKK di desa Sukaresik, Kecamatan Sindangkasih, Kabupaten Ciamis.

Kegitan pengabdian ini memiliki relevansi dengan kebutuhan ibu-Ibu PKK. Media pengajaran dan metode pembelajaran percakapan bahasa Inggris yang menarik akan memotivasi siswa untuk terlibat dalam kegiatan percakapan bahasa Inggris. Para ibu-ibu PKK memiliki pengalaman baru belajar bahasa Inggris.

Berdasarkan wawancara, tanya jawab dan pengamatan langsung selama kegiatan berlangsung, kegiatan pengabdian pada masyarakat ini memberikan hasil berupa meningkatnya pengetahuan dan pemahaman ibu-Ibu PKK desa Sukaresik dalam menggunakan bahasa Inggris untuk bisnis dan bahasa Inggris untuk pariwisata dengan menerapkan role play di daerah sekitar wisata sungai Cireong.

Faktor pendukung dan faktor penghambat yang mendukung terlaksananya kegiatan pengabdian kepada masyarakat ini adalah pihak PKK desa Sukaresik sangat mendukung terlaksananya kegiatan, serta besarnya minat dan antusiasme peserta selama kegiatan, sehingga kegiatan berlangsung dengan lancar dan efektif. Sedangkan faktor penghambatnya adalah keterbatasan waktu pelatihan.

\section{KESIMPULAN DAN SARAN}

\section{Kesimpulan}

Kesimpulan dari kegiatan pengabdian kepada masyarakat ini adalah: 
Pemberdayaan Ibu-ibu PKK Melalui Pelatihan English For Business Dan English For Tourism di Desa Sukaresik Kecamatan Sindangkasih

1. Peningkatan pengetahuan dan pemahaman Ibu PKK tentang English for Business dan English for Tourism dalam percakapan bahasa Inggris.

2. Peningkatan pengalaman baru dan keterampilan Ibu-Ibu PKK tentang English for Business dan English for Tourism dalam percakapan bahasa Inggris.

\section{Saran}

Mengingat besarnya manfaat kegiatan pengabdian kepada masyarakat ini, maka disarankan perlu:

1. Mengadakan pelatihan yang sama terhadap materi bahasa Inggris yang berbeda dengan khalayak sasaran yang lebih banyak.

2. Mengadakan pelatihan tentang media pengajaran dan metode pembelajaran bahasa Inggris yang efektif dan efisien untuk ibu-ibu PKK.

\section{DAFTAR PUSTAKA}

Ali, Isbandi Rukminto. (2008). Intervensi Komunitas Pengembangan Masyarakat sebagai Upaya Pemberdayaan Masyarakat. Jakarta: Rajawali Pers.

Anshar, M. (2017). Peran dan Dampak Program Pemberdayaan dan Kesejahteraan Keluarga Terhadap Kesejahteran Ekonomi Keluarga Kelurahan Sei Kera Hilir II Kota medan. Journal of Islamic Law. Vol 1. No 2. July-December 2017

Evan H. (2015).Pentingya Bahasa Inggris Bisnis dalam Dunia Usaha. www.linkedin.com

Fatchur. (2015). Peran Bahasa Inggris dalam Dunia Bisnis. http.www.es indonesia.com

Nina dkk (2017). Pelaksaan Peran Tim Penggerak Pemberdayaan dan Kesejahteraan Keluarga dalam memberdayakan perempuan. Jurnal Administrasi Publik Vol 2 No 5

Nugroho, Heru (1999). Kemiskinan dan Kesenjangan di Indonesia: Kemiskinan, Ketimpangan danPemberdayaan.Yoyakarta: Adtya Media.

Permendagri Nomor 1Tahun 2013. Pemberdayaan Masyarakat Melalui Gerakan Pemberdayaan Dan Kesejahteraan Keluarga. Jakarta: Menteri Hukum dan Hak Asasi Manusia Republik Indonesia.

Rais dkk. (2013). Pemanfaatan Media APE PKK Kelurahan Margohayu Kecamatan Karang Wetan Kabupaten Demak. Jurnal Prngabdian Kepada Masyrakat. Vol 4. No 2. 2013 